\title{
LA CREACIÓN DE LA NOUVELLE FEMME EN EL PARAÍSO DE LAS DAMAS, DE ÉMILE ZOLA
}

\author{
CARMEN ÁLVAREZ LOBATO \\ Universidad Autónoma del Estado de México \\ caralvo@gmail.com \\ ORCID: 0000-0002-6922-2635
}

\section{RESUMEN}

Este artículo analiza la novela El paraíso de las damas, de Émile Zola, desde el marco de la modernización de París durante el Segundo Imperio. Se estudia, fundamentalmente, la transformación del ser social y la creación de un nuevo personaje: la nouvelle femme, encarnada, en la novela, por Denise Baudu. El artículo expone el marco irónico de la novela y dialoga con la teoría del hombre nuevo de Henri de Saint-Simon. Se argumenta que Zola propone, desde este personaje femenino, que un cambio en el entorno es propicio para el desarrollo de mujeres y hombres naturales; la nouvelle femme es el nuevo elemento capaz de crear un gran cambio social a través del trabajo y la virtud.

PALABRAS CLAVE: mujer nueva, transformación social, Zola, El paraíso de las damas.

\section{THE CREATION OF LA NOUVELLE FEMME IN ÉMILE ZOLA'S THE LADIES' PARADISE}

\section{ABSTRACT}

This article analyzes the Emile Zola's novel The Ladies'Paradise, within the framework of Paris modernization of the Second Empire. The document studies, fundamentally, the transformation of social being and the creation of a new character: la nouvelle femme, played by Denise Baudu. The article exposes the ironic framework of the novel and dialogues with the new man's concept of Henri de Saint-Simons. It is argued that Zola proposes, from the point of view of his female character, that a change in the environment is conducive to the development of natural women and men; la nouvelle femme is the new element capable of creating a great social change through work and virtue.

KEYWORDS: new woman, social transformation, Zola, The Ladies' Paradise. 
Le vieux Paris n'est plus (la forme d'une ville Change plus vite, hélas! que le cœur d'un mortel) Baudelaire, «Le Cygne»

El paraíso de las damas (1883), ${ }^{1}$ novela naturalista de Émile Zola, es el volumen undécimo de los veinte que componen la saga familiar Los Rougon-Macquart. Historia natural y social de una familia bajo el segundo imperio (1852-1871) escritos entre 1871 y 1893. Zola dedica dos volúmenes a la narración de la vida de Octave Mouret (hijo de Marthe Rougon y François Mouret): el décimo, intitulado precisamente Octave, Pot-Bouille (1882), donde se narran los difíciles inicios del personaje en París, y El paraíso de las damas, donde se relatan sus éxitos sociales y económicos.

Una primera lectura de la novela puede ofrecer una perspectiva naturalista aparentemente sencilla; parece que Zola subrayara la historia amorosa entre el magnate del comercio Octave Mouret, viudo, joven, codicioso y algo cínico y la joven provinciana Denise Baudu. En la novela, el magnate está abocado a dos objetivos: agrandar su Grand Magasin, «El paraíso de las damas», a costa de la desaparición de los pequeños comercios tradicionales parisinos, por un lado; intención que se empequeñece ante su segundo objetivo, aún más importante: doblegar a sus competidores, pero, fundamentalmente, doblegar, complaciendo, a las damas parisinas. Parece ser, como el mismo personaje manifiesta varias veces, que el centro de su lucha es la posesión femenina:

las clientes, despojadas, forzadas, se marchaban, medio rendidas, con la misma voluptuosidad satisfecha y la misma vergüenza sorda que proporciona la consumación de un deseo en lo más recóndito de un hotel de mala fama. Y era él quien las había poseído así. (p. 303)

La resolución que otorga Zola a la vida de este, en muchos momentos, libertino personaje, es inusualmente optimista y propositiva: el joven Mouret logra un éxito total, ya que agranda sus almacenes, doblega a la aristocracia parisina y sus cercanos competidores no logran hacerlo tambalear (con algo de mofa, incluso, el autor escribe cómo el empleado Bourdoncle y la ex amante Henriette, asociados en contra de Octave, crean un establecimiento similar, que acaba consumido por las llamas). Sin embargo, a pesar de sus éxitos y riquezas Mouret no es dichoso: se enamora de una de sus empleadas, la inocente Denise, recién llegada de la provincia de Valognes. Octave, acostumbrado a solicitar y obtener los favores de sus empleadas, encuentra en Denise una férrea resistencia... hasta que pasados los años y al final de la novela, Mouret sucumbe ante el amor y le pide matrimonio a la virtuosa joven en una propuesta no exenta

\footnotetext{
${ }^{1} \mathrm{Au}$ bonheur des dames, en castellano «La felicidad de las damas» $\mathrm{O}$ «La dicha de las damas» en estricto apego al original en francés. Utilizo en este artículo la edición de Émile Zola, El paraíso de las damas, editada por Alba (Zola 1999).
} 
de ironía por parte del autor. ${ }^{2}$ Zola coloca a su personaje dentro del tópico del cazador cazado: el hombre que busca el sometimiento femenino termina por ser vencido por una mujer.

Así, esta primera lectura de la obra se inscribiría en el fácil terreno de la novela sentimental, con un tratamiento tradicional y un final feliz: el hombre exitoso y libertino encuentra el amor y se redime gracias a una buena, trabajadora y nada pizpireta mujer de provincia. El hombre de mundo es vencido por la virtud; las clases sociales, los prejuicios, quedan borrados, no hay impedimentos para el amor ni para el ascenso social.

Sin embargo, esta novela resulta peculiar tanto en el tema como en su tratamiento. Del ciclo de Los Rougon-Macquart probablemente sea la única que deroga el «pesimismo naturalista» cambiándolo por un inusual, para Zola, optimismo en las posibilidades humanas; sin duda se trata de un exaltado himno al comercio y a la modernidad, pero también a la creación de un nuevo modelo social. En esta novela las clases sociales prácticamente se difuminan y se acaba con el determinismo histórico: dignifica el trabajo o la virtud, no la sangre ni el conocimiento. El locus de esta igualdad es París, ciudad que en el siglo XIX se pensó, junto con Londres, como una suerte de utopía, esto debido en gran medida a la enorme transformación urbana llevada a cabo durante el Segundo Imperio.

Pero, no debe olvidarse que Zola era acérrimo crítico del Segundo Imperio, de la impostura de Napoleón III y de la visión exclusivamente «modernizadora» de París; de ahí que sus novelas muestren constantemente las fisuras de este modelo transformador. El ciclo de Los Rougon-Macquart no es sino una detallada explicación de esta postura crítica a tono con el subtítulo de la saga: Historia natural y social de una familia bajo el segundo imperio. Así, el autor cuestiona las intenciones napoleónicas y exhibe los detritus de la modernidad; sus narradores y personajes van de la atracción a la repulsión por la ciudad parisina y ascienden tanto como descienden en la escala social.

En estas novelas el autor francés toma la pauta histórica del crecimiento de París durante el Imperio de Napoleón III, llevado a cabo por el Barón Haussmann, prefecto del Sena, entre 1853 y 1870. Por primera vez en siglos cambia y se transmuta el escenario físicamente, lo que motiva el lamento de Baudelaire con el que inicio este artículo pero que subraya, precisamente, el movimiento de la gran urbe que promueve el movimiento social.

${ }^{2} \mathrm{El}$ marco en que se inscribe esta novela es uno irónico con componentes satíricos; la ironía, figuración literaria que marca diversos contrastes desde una postura relativamente disimulada es «estructura antifrástica y estrategia evaluativa», fundamentalmente crítica (Hutcheon 1992: 177). La crítica que ejerce Zola en esta novela se da desde diversos contrastes que marcan el gran abismo entre los viejos y los nuevos valores, entre una sociedad aristocrática empobrecida y un ascenso de nuevos actores económicos; está ironía marca, sobre todo, un desfase temporal que muestra las fisuras de la sociedad parisina del siglo XIX, de allí su relación con la sátira: «Si la ironía es siempre a expensas de alguien o de algo, es de este funcionamiento pragmático (y no semántico) que deriva la adecuación del uso satírico de la ironía burlona, despreciativa» (Hutcheon 1992: 179). 
Este cambio de paradigma, esta entrada a la modernidad, afecta, por supuesto, el escenario, la economía y los roles sociales:

En «El Paraíso de las Damas», en efecto, se reflexiona a propósito de la "nueva modernidad". Para que el "negocio especulativo" se consolide y adopte formas irreversibles es necesario enterrar el "modelo tradicional", referido, en esta ocasión al "pequeño comercio", a favor del Gran Almacén «El Paraíso de las Damas». Y para ello la ciudad tiene que cambiar, ya que la nueva dimensión comercial que se deriva del Gran Almacén, cuantitativa como cualitativamente, exige reconsiderar la "centralidad" tradicional. Es así como Mouret, el dueño del «El Paraíso de las Damas», considera necesario e imprescindible, para garantizar su éxito económico, la presencia de una gran avenida, de un nuevo "boulevard", que proporcione accesibilidad a su negocio y, al mismo tiempo, sirva de escaparate para exponerlo a los ojos de todos. (Álvarez Mora 2008: 278)

Los llamados «trabajos haussmanianos» cambiaron el panorama del centro del París del Segundo Imperio convirtiéndola en el epítome la ciudad moderna europea, en la aparente concreción de una utopía. Se crearon nuevas calles y bulevares, eficaces redes de alcantarillado y agua, novedosos espacios verdes, monumentos públicos, edificaciones y fachadas; se anexaron también algunos barrios periféricos y se transformó para siempre la fisonomía de París. Cambia la vieja Île de la Cité, anteriormente con un tejido medieval desorganizado, calles estrechas y problemas de circulación e insalubridad. La nueva traza busca «abrir», «ordenar»y tener un mejor control de la ciudad gracias a una mejor circulación, economía e higiene.

La creación de esta nueva ciudad tiene también una importante lectura simbólica, ya que «evapora el pasado» y modifica la memoria histórica: las murallas medievales son sustituidas por amplios bulevares, los nuevos monumentos reemplazan a los antiguos. Se prefiere la línea recta a la curva, el orden por encima del caos, y se continúa con la analogía geometría/orden ya iniciada en el Renacimiento:

se complementó con otra simétrica que consistió en la evaporación del pasado: los siglos XV-XVI, lejos de efectuar un renacimiento del clasicismo, cumplieron su transportación al universo de las formas. Al incorporarlo al orden de los signos, establecieron el primer y esplendoroso modelo cultural operativo de la modernidad, preanunciando la más vasta transustanciación del pasado que efectuaría el historicismo del XVIII-XIX. La palingenesia renacentista facilitó la expansión de Europa y fue decuplicada por la palingenesia del Iluminismo que sentó las bases de la dominación universal. (Rama 1998: 24)

Es así como, sobre todo en años recientes, El paraíso de las damas ha sido leído como un documento histórico o como una suerte de mapa urbano, de referente para los estudiosos de los nuevos modelos de consumo o de la gentrificación. La detallada descripción del centro comercial y del cambio de la ciudad sin duda permite dichas lecturas, pero me parece que la intención del autor es poner en el centro de la discusión una probable reconciliación entre el mundo rural y la reciente urbanización, lo que le permite también crear un nuevo modelo social y 
una nueva protagonista: la nouvelle femme. La peculiaridad de El paraíso de las damas estriba en que, sin abandonar su crítica al modelo napoleónico, busca una salida utópica social, la creación de hombres y mujeres nuevos: la parte luminosa del monstruo del progreso. Incluso, el autor se deja seducir por la nueva belleza de la ciudad, adelantándose al futurismo de Marinetti de inicios del siglo XX afirmando, décadas antes, la belleza del nuevo paisaje urbano, cantando la fuerza de la modernidad y de las máquinas:

Entre el perturbado sueño de barrio, el tajo, que agigantaba aquella claridad lunar, parecía colosal y fantástico; bullían por él negras sombras, fragorosos obreros cuyas siluetas gesticulaban contra la cruda blancura de las paredes nuevas. (pp. 158-159)

El paraíso de las damas tiene como tema central el de la movilidad, y no me refiero exclusivamente a la movilidad derivada de la nueva traza urbana, sino a la movilidad social; la nueva ciudad permite la circulación del aire, del dinero y de nuevos personajes. Extraño optimismo que, en todo caso, el autor sólo mostraba en sus ensayos, no en sus obras narrativas. Mucho se ha insistido en la brecha que existe entre el Zola novelista y el Zola teórico; sin embargo, en este caso, sí parece haber cierta coherencia entre el texto programático y el literario. Por ejemplo, afirma el novelista con respecto al determinismo:

Enseñamos el mecanismo de lo útil y de lo nocivo, desligamos el determinismo de los fenómenos humanos y sociales a fin de que un día se puedan dominar y dirigir estos fenómenos. En una palabra, trabajamos con todo el siglo en la gran obra de la conquista de la naturaleza y el poder multiplicado del hombre. (Zola 1972a: 51)

Las taras familiares, la locura, la debilidad corporal que aqueja a todos Los Rougon-Macquart son eludidos en esta novela; acaso, los vicios de Octave Mouret son «curados» finalmente por el amor. ${ }^{3} \mathrm{Y}$ es también interesante cómo, de toda la saga familiar, ésta es la única novela que lleva como título el nombre de un gran almacén (aunque algún esbozo estaba ya en la tercera novela del ciclo: $E l$ vientre de París, donde el protagonista es el mercado central de París) convirtiéndose a veces, mediante prosopopeya, en protagonista del relato, un monstruo maravilloso, prácticamente el centro de la actividad parisina de la época. ${ }^{4}$

${ }^{3}$ Parece ser que Zola se basó en la historia de Cognac, fundador del almacén La Samaritaine, quien se casó con una de sus empleadas. Por aquellos tiempos triunfaban también los Grands Magasins du Louvre, Le Bon Marché, Le Printemps y La Belle Jardiniére (Cfr. Gallego y García, nota a Zola 1999: 2). Tiempo después, y aprovechando el éxito de estos grandes almacenes, surgen las famosas Galeries Lafayette.

${ }^{4}$ La saga está compuesta por los siguientes títulos: 1 . La fortuna de los Rougon; 2. La jauría; 3 . El vientre de París; 4. La conquista de Plassans; 5. El pecado del Abate Mouret; 6. Su excelencia Eugène Rougon; 7. La taberna; 8. Una página de amor; 9. Nana; 10. Octavio (Pot-Bouille); 11. El paraíso de las damas; 12. La alegría de vivir; 13. Germinal; 14. La obra; 15. La tierra; 16. El sueño; 17. La bestia humana; 18. El dinero; 19. La debacle; 20. El doctor Pascal (Cfr. Zola 1960-1967). 
El autor dedica infinidad de páginas a la descripción detallada de los almacenes desde sus inicios hasta su éxito colosal (sabemos, por la edad del hermano menor de la protagonista, Pépé, quien llega a París a la edad de cinco años y se le ve al final como un muchacho de doce, que la narración abarca siete años). Escritor afincado en el detalle, en la observación, en la experimentación, el retrato que Zola da de la situación del París de la época es bastante preciso desde el comienzo: la novela inicia con la llegada de los hermanos Baudu, los inocentes Denise, Jean y Pépé a París. Se observa de inmediato la predilección que tiene el autor por la ciudad, contrariando algunos de los tópicos de la novela realista y naturalista hasta entonces que de algún modo derivaban del tópico horaciano del beatus ille al presentar la contraposición ciudad/aldea: la ciudad como fea, artificiosa, vil y el campo como espacio de la virtud, la paz y la generosidad. De este tópico Zola mantiene la evaluación moral: el vicio urbano y la virtud provinciana; se permite incluso una analogía entre las líneas curvas representativas del caos medieval, la vieja París, y su transformación en la moderna París, ordenada y geométrica, con sus correspondencias en el ser social al presentar a Octave Mouret como el libertino retorcido y a Denise Baudu como la rectitud de la virtud.

En ese sentido, la lectura del autor es clara: la provincia no tiene ya posibilidades sociales ni económicas, pero se rescata la virtud de los hombres naturales: gracias a esa virtud se verá más adelante cómo Denise (ya convertida en una figura primordial en los almacenes) logra significativas mejoras laborales. Lo importante es, pues, trasladar esa virtud de la gente sencilla a la ciudad, corrompida por los vicios de la burguesía y la aristocracia. Para lograr este cometido la estrategia narrativa que se utiliza de inmediato es la del contraste: los jóvenes de provincia arriban a París a raíz de la muerte de sus padres; las primeras descripciones abundan en su luto riguroso aunado a su evidente pobreza. Son nuevos personajes que irrumpen en la ciudad: seres solitarios, abandonados, huérfanos en todo el sentido de la palabra —de sus padres y del Estado- pero que, de algún modo, logran salvarse de un orden injusto. Sus características físicas ostentan una mezcla de miseria, desconsuelo e inocencia, parecen vivir en un «estado de naturaleza»:

La atónita Denise parecía aún más delgada, con aquel rostro afilado, de boca demasiado grande y cutis ya marchito bajo el cabello pálido [...] aquella joven triste entre aquel precioso niño y aquel espléndido adolescente, los tres tan rubios y tan humildemente vestidos de negro, formaban un cuadro tan peculiar y lleno de encanto, a pie firme en mitad de la calzada, que los transeúntes se volvían para mirarlos con una sonrisa. (p. 6)

Mientras, el narrador omnisciente destaca una y otra vez el colorido y el lujo representados por la tienda de novedades «El paraíso de las damas»:

una orgía de colores, un regocijo callejero que estallaba en aquella esquina, en aquel rincón dedicado por completo al consumo, abierto de par en par, al que todo el que quisiera podía acudir a alegrar la vista. (p. 65) 
Zola se muestra seducido por dicho almacén, aunque su intención está lejos de ser frívola; al contrario, utiliza al establecimiento como sinécdoque del París moderno. Aparentemente la narración del naturalista no trasciende las meras descripciones detalladas de la alta sociedad ubicada en unas cuantas cuadras de un barrio parisino, cuyo centro es precisamente el almacén; sin embargo, lo que de hecho narra es el cambio paulatino de la sociedad tradicional europea a una sociedad moderna. Así, la llegada de los jóvenes Baudu a París, además de otorgar el componente de inocencia positiva al que me he referido antes, manifiesta el éxodo natural de la provincia atraída hacia la fuerza centrípeta de las grandes urbes, las cuales prometen mejores condiciones de vida mediante arduo trabajo: único y efectivo medio de ascenso social, «la aristocracia del trabajo» pregona Mouret. El caso de los jóvenes Baudu no es único, Zola muestra cómo los orígenes de buena parte de los empleados de «El paraíso de las damas» son similares a éstos. Por supuesto, esta lectura es complejizada ya que, sugiere el autor, sin el debido cuidado, el hombre natural también es corrompido; muchos de los empleados del almacén ceden a la seducción del lujo y el mundo de las apariencias de la gran ciudad y terminan pervirtiéndose, mientras que Denise se salva, salva a su familia, a Mouret, y al mismo almacén, resguardándose siempre en su integridad.

Para el autor, la modernidad es inminente, puede ser que hasta positiva, de ahí que el tratamiento que da al «antiguo comercio» sea más bien negativo. Los niños llegan a París buscando el amparo del tío Baudu, quien vive y tiene su pequeño comercio de telas precisamente en la acera de enfrente de «El paraíso de las damas». Continúan los contrastes: el tío, representante del comercio tradicional, apenas puede mantener a su establecimiento y a su familia debido a la dura competencia que le representa el gran almacén. Su establecimiento, «El viejo Elbeuf», es pequeño, sucio, oscuro y sórdido:

A ambos lados de la puerta, en un marco de madera del mismo verde botella del rótulo, que el tiempo había teñido de ocre y hollín, se abrían dos hondos escaparates, oscuros y polvorientos, en los que apenas se distinguían las piezas de paño que en ellos se amontonaban. La puerta, abierta de par en par, parecía la boca de un húmedo y tenebroso sótano. (p. 7)

Así como tenebroso resulta también el aspecto de los parientes citadinos: el tío Baudu es descrito como un hombre decrépito y amarillento, su esposa como una mujer blanquísima y anémica y la prima Geneviéve como una chica macilenta «cuya sangre estaba aún más empobrecida que la de su madre, era frágil y descolorida como las plantas que crecen sin sol» (p. 9). Las descripciones del «El paraíso», mientras tanto, son amplias, abiertas, luminosas y llenas de vida.

De tal manera, el antiguo comercio, y con él la sociedad tradicional parisina, representan lo viejo y enfermo, mientras que el nuevo almacén simboliza no sólo la modernidad de la ciudad y el comercio, sino también la llegada del nuevo orden social al que me he referido y que es, para Zola, bastante más saludable. 
De hecho, a medida que el almacén crece y comienza a engullir a los comercios aledaños, los personajes que representan lo viejo y caduco no sólo no encuentran su lugar en la nueva sociedad, sino que mueren. La valoración de los jóvenes Baudu es también bastante clara, el pequeño comercio de su tío les produce miedo, «El paraíso de las damas», fascinación. Juega incluso Zola con el nombre de una de las telas que Mouret vende en su establecimiento, de donde quizás proviene la traducción al castellano del título de la novela: se le trata de la seda París-Paraíso (en francés el juego de palabras es más claro: Paris-Paradis). Y se ve en varios momentos cómo el almacén resulta una suerte de Paraíso para los jóvenes recién llegados. No deja de haber cierta ironía por parte del autor, ya que traslada la mítica Edad de Oro al Paraíso de las compras, sí, probablemente, el nuevo sitio de la «igualdad» social. La lectura que hace Zola sobre la modernidad y el consumo es, en todo caso, compleja.

El almacén «El paraíso de las damas» tiene una valoración ambigua, tanto positiva como negativa, del nuevo ordenamiento del centro de París, y con éste, de las nuevas edificaciones y los recientes modos de vida. No todo es una crítica al voraz capitalismo que cercena los modos de vida tradicionales, pero el autor tampoco está interesado en idealizar las taras, económicas y sociales, que alberga el viejo París. Entre las características negativas la novela destaca el cinismo y egoísmo de parte de Mouret; frivolidad, carencia de virtud e imitación acrítica de modos de comportamiento burgueses de los empleados del almacén; soberbia, hipocresía y afirmación de las apariencias por parte de las clientas del almacén. Quizás la crítica más fuerte sea hacia la aristocracia (por lo general, empobrecida, ya económicamente, ya moralmente) que ama el mundo de las apariencias y la «honestidad» pero que manifiesta comportamientos poco dignos. No obstante, todo esto parece ser corregido mediante la fuerza virtuosa de Denise: la muchacha cambia el comportamiento cínico de Octave Mouret y con esto, logra mejoras laborales para los empleados de «El paraíso»: mejores horarios, habitaciones, alimentación:

En vez de los despidos en masa, se fue organizando un sistema de permisos durante las temporadas bajas; $y$, por fin, iba a fundarse muy pronto una caja de solidaridad que pondría a los empleados al amparo del paro forzoso y les garantizaría una pensión. Era éste el embrión de las grandes asociaciones obreras del siglo XX. (p. 254)

Además, se disminuye la carga laboral de las empleadas y se crean nuevos puestos de trabajo: «unas ayudantas que se hacían cargo de las compras, lo que suponía un alivio para las cansadas dependientas» (p. 291). Aún más, se plantea la posibilidad de que los empleados del almacén disfruten de las actividades favoritas del ocio aristocrático e incluso que tengan acceso al conocimiento:

Llegó incluso a haber clases de equitación y de esgrima. Se creó una biblioteca: diez mil volúmenes a disposición de los empleados. Y también hubo un médico permanente, que pasaba consulta gratis; baños, bufés; un salón de peluquería. (p. 254) 
Por otra parte, las clientas soberbias de «El paraíso de las damas» encuentran su castigo: la condesa De Boves es sorprendida robando «robaba por el gusto de robar» (p. 300) y es exhibida por los empleados, ante quienes pierde la compostura: «La belleza de Juno, la majestuosa complexión del cuerpo se le desbarataban en una bronca de verdulera» (p. 301); la empobrecida señora Marty deja en la bancarrota a su marido; la frívola marquesa Henriette Desforges no tiene más remedio que pedirle a Mouret que dé empleo, como dependienta, a su protegida, la joven marquesa De Fontenailles. La sátira de Zola queda de manifiesto cuando, en su novela, esta aristocrática muchacha se casa con un mozo de almacén, el estrato más bajo de los empleados de «El paraíso», y sirve fielmente a Denise, la otrora desdichada provinciana.

Las aristócratas que aún conservan su riqueza reciben también un escarmiento: la ex amante de Mouret, Henriette, quien humilla en más de una ocasión a Denise, acaba siendo despreciada por Octave:

Henriette, tras quedarse sin respiración, había sacado el pañuelo y se lo estrujaba contra los labios. Todos los planes le habían salido al revés y se veía atrapada en su propia trampa. Sentía el desconsuelo de haber llevado las cosas demasiado lejos y el tormento de los celos. ¡Que la abandonasen por una mujerzuela como ésa! ¡Verse desdeñada en su presencia! Padecía más en ella el orgullo que el amor. (p. 230)

El paraíso de las damas deja al descubierto las inconsistencias de un orden social y económico que se viene abajo en la modernidad; en el volumen décimo del ciclo, Pot-Bouille, Zola muestra los orígenes provincianos de Octave, allí:

\footnotetext{
Mouret representa a la segunda oleada de beneficiarios de los grands travaux: los nuevos empresarios que no forman ya parte de la jauría especuladora [...] sino que vienen a instalar sus actividades comerciales o industriales en el tejido urbano y social recién creado, comprendiendo a la perfección las nuevas reglas de juego de la ciudad mercantilizada y relegando al olvido a las formas tradicionales del comercio y la distribución [...] Pero, antes de llegar al irresistible triunfo de Mouret, que culminará en Au Bonheur des Dames, con la creación del primer gran magasin de la capital francesa, su nueva personalidad urbana deberá cimentarse en el auténtico rito de iniciación que supone, para él, recién llegado de provincias, el conocimiento directo, a partir del humilde comienzo de una simple habitación alquilada. (Calatrava 2007: 243)
}

En Pot-Bouille el joven Octave se muestra deslumbrado por la rica París, y después se ve desengañado al conocer el vicio, la doble moral y las ocultas intenciones de los ricos habitantes de la ciudad. Él mismo llega como vendedor al almacén «El paraíso»; Denise no sería sino la contraparte femenina de Mouret con una importante diferencia, ella no se deja corromper. El conocimiento previo del joven es el que le permitirá posteriormente manipular a las clases adineradas en El paraíso de las damas. De una novela a la otra Octave Mouret ha cambiado de comportamiento y de clase social; ahora pertenece a la nueva clase media alta que se codea con la aristocracia, de allí que, en su discurso a lo largo de la novela, presuma que se pueda avanzar socialmente a través del trabajo arduo. No deja 
de haber una gran ironía por parte de Zola ya que Mouret realmente no ha escalado gracias al trabajo honrado, sino porque ha heredado el almacén de su difunta y rica esposa, Madame Hédouin.

Esta clase adinerada parisina queda representada por los siguientes personajes: condes y barones que fungen como prestigiosos abogados, ministros del gobierno y funcionarios de diferentes órdenes; en otro estrato, los oficios medios: médicos y profesores. Hay asimismo una fuerte crítica a las profesiones predilectas del liberalismo que tienen cierto abolengo pero que son mal pagadas:

La eterna historia de tantos jóvenes pobres, que creen que su cuna sólo les permite ejercer profesiones liberales y se entierran en una vanidosa mediocridad, con los cajones llenos a reventar de títulos, dando gracias si no consiguen morirse de hambre. (p. 49)

Octave encuentra, pues, como único medio para avanzar económica y socialmente, el comercio: menos estudios, menos títulos y más dinero, así lo afirma:

Cuando conseguí el título de bachiller, podría haberme hecho abogado o médico, igual que tantos compañeros; pero me asustaron esas profesiones; están sobradas de gente que pasa apuros... Así que me despedí de la panza de burra, sin arrepentirme de nada, no vayas a creer, y decidí probar suerte en los negocios. (pp. 49-50)

Se subraya el trabajo por encima de la sangre y del conocimiento, con lo que de un tajo Zola descalifica tanto al modelo tradicional como al sistema liberal. El nuevo mundo, afirma el autor, está regido no tanto por el dinero, sino por el trabajo y la voluntad humanas:

Está la voluntad de querer y de hacer, de crear [...] sólo los inválidos de cuerpo o de pensamiento se hurtaban al trabajo en una época en la que había tanto por hacer, mientras el siglo entero se abalanzaba hacia el futuro. Y se mofaba de los desesperados, de los asqueados, de los pesimistas, de todos los inválidos de aquel alborear de las ciencias, de su plañidero llanto de poetas o de su altanería de escépticos, en medio del gigantesco tajo de la era contemporánea. (p. 51)

Desde el naturalismo, el escritor se separa de una novela decimonónica tradicional nacida desde la perspectiva de las clases adineradas. Los satiriza porque la literatura ya no corre paralela a los intereses de la nobleza, ésta ha desaparecido:

La nobleza ha sido herida de muerte. Abandona su gran tren, baja la cabeza poco a poco ante el nivel igualitario. Es una decadencia lenta y fatal, que no le permitirá ya tener sus poetas y sus historiógrafos. (Zola 1972b: 161)

Zola narra detalladamente en qué radica el éxito de «El paraíso de las damas»: el sistema del libre mercado y de la competencia descarada, las 
estrategias de marketing, ${ }^{5}$ las trampas a la clientela, situaciones que no son vistas del todo de manera negativa por el autor, ése es el nuevo orden de las cosas:

Nos esforzamos exclusivamente en librarnos rápidamente de los géneros que adquirimos para sustituirlos por otros nuevos, con lo que logramos que el capital rinda interés tantas veces cuanto esto sucede. (p. 56)

Se busca seguir una estrategia contraria a aquella de los almacenes tradicionales: vender mucho a bajos precios y no a la inversa, poco a costos elevados. En el centro de la competencia el almacén se aprovecha del consumismo frenético de las mujeres pertenecientes a la aristocracia y a la alta y mediana burguesías:

El arte de explotar a la mujer [...] la continua renovación del capital; la acumulación de mercancías; la tentación de lo barato; los precios marcados, que inspiran confianza. (p. 57)

De esta manera, «El paraíso de las damas» disloca el orden social y económico, tanto tradicional como liberal. Ciertamente en los almacenes se observa el mundo de las apariencias y de la frivolidad y de la acumulación acrítica de objetos superfluos pero al mismo tiempo Zola afirma que, a pesar de eso, el almacén promete a sus empleados mejores condiciones de vida y una posibilidad real de ascenso social (lo que de ningún modo prometía el viejo régimen monárquico y que quedó como una promesa sin cumplir del liberalismo), esto parece ser suficiente excusa para permitir el engaño y la competencia comercial. De hecho, el almacén parece ser el único sitio de París que da muestras de cierta democracia:

Era aún una muchedumbre muy variopinta, aunque en las primeras horas de la tarde acudían más damas, que se mezclaban con las pequeñas burguesas y las amas de casa. (p. 180)

Entra aquí el cambio del escenario urbano. Mouret se asocia con el Barón Hartmann (evidente reescritura del histórico Barón Haussmann) presidente del Banco de Crédito Inmobiliario, quien compra el palacete de Duvillard para que el almacén pueda expandirse; «El paraíso de las damas» se extiende a los edificios contiguos y en torno a él se da la nueva planificación urbana. Todo esto acaba por afirmar el fin de la antigua ciudad, los nuevos almacenes ocupan las instalaciones de los viejos palacios. La demolición de los rancios edificios y la construcción de los nuevos acaban por colapsar al antiguo mundo del comercio y la modernidad se hace presente con toda su fuerza:

En septiembre, el arquitecto, temeroso de no cumplir los plazos, tomó la decisión de seguir trabajando durante la noche. Colocaron potentes focos eléctricos y el estruendo fue ya

\footnotetext{
${ }^{5}$ Se observan los inicios del mundo de la publicidad: carruajes que pasean por París con la leyenda de los almacenes y anuncios en los periódicos. Además, Zola detalla la importancia de la belleza de los escaparates, de la disposición de las mercancías en la tienda, del sistema de devoluciones, rebajas, etcétera, como componentes fundamentales del comercio moderno.
} 
permanente. Las cuadrillas se iban turnando; los martillos no se detenían nunca; las máquinas silbaban de continuo; parecía que el clamor, que no remitía nunca, alzaba y esparcía el yeso. (p. 158)

Se trata de un modelo moderno que involucra aspectos económicos y sociales y que tiene como centro la ciudad y en la novela, como sinécdoque, al gran almacén. Éste es admirado por su novedad, por sus aspectos utópicos, pero también repudiado por limitar la libertad de pensamiento y someter a la población a gustos comunes, ya que cambia la especialización propia de los pequeños comercios por una exposición variopinta y desvergonzada. Zola expone la enorme transformación del ser social en estricto apego al ser urbano, pero se cuida de hacer una lectura maniqueísta: no todo cambio urbano es negativo, pues la transformación también implica un mejor acceso de los «de abajo» a los modelos de las clases altas. Lo que libra a la novela de una visión exclusivamente consumista y cínica es la presencia de los hermanos Baudu, ya que ellos representan un nuevo tipo social: el provinciano que triunfa en la ciudad por medio del trabajo honesto sin perder su virtud.

Denise, de manera especial, funciona como conciencia crítica, sabedora de la nueva clase social que se está forjando, pero no sin mirar aterrada cómo desparece lo antiguo, cómo la nueva ciudad se construye sobre los despojos de la anterior, pero cómo es ésta, quizás, la única opción de ascenso:

¡Familias que lloran, ancianos que se ven en el arroyo, todos los dolientes dramas de la
ruina! Y ella no podía salvar a nadie; y era consciente de que se trataba de algo beneficioso,
la salud del París del mañana precisaba de aquel estiércol de desdichas [...] Sí, era el tributo
de la sangre; toda revolución exigía mártires; sólo se podía avanzar pisando cadáveres. Su
temor de ser un alma perversa, de haber colaborado en el asesinato de sus seres más
queridos se iba convirtiendo en una consternada compasión ante aquellos males
irremediables, que son los dolores de parto de todas y cada una de las generaciones. Acabó
por ponerse a pensar en los posibles alivios; su bondad estuvo mucho tiempo soñando con
los medios que habría que adoptar para salvar al menos a los suyos del aplastamiento final.
(p. 268)

La novela genera así un nuevo mito social, no es, como en otras novelas adscritas a proyectos liberales, la educación la que funciona como palanca del ascenso social, sino la creación de un nuevo centro económico. En el siglo XIX se instauran espacios más libres, probablemente menos dependientes del Poder y con un reconocimiento al esfuerzo individual; hay una naciente ampliación de la base económica. Denise ni quiere ni puede convertirse en institutriz, maestra, enfermera o en representante de otro ejercicio «liberal»; asciende primero desde el trabajo y se consolida social y económicamente desde el matrimonio. El ciclo de Los Rougon-Macquart muestra la complejidad económica y social del Segundo Imperio; sus promesas, algunas cumplidas y otras sin cumplir, en el marco de una modernización que benefició a algunos pero que aniquiló a otros.

Denise está totalmente alejada de cualquier estructura de poder, incluso de la primera célula de la sociedad, su familia parisina, la cual desde un inicio la 
rechaza. La joven triunfa solo con sus capacidades individuales; éstas no son la fuerza, la argucia o el estudio, sí el trabajo y la virtud. La muchacha no queda integrada a una pauta educativa, sino a un modelo económico y, más aún, a un esquema familiar tradicional. Su éxito final es el matrimonio, visión sumamente tradicional por parte de Zola, correspondiente, por supuesto, al modelo hegemónico de la época. Como en toda novela realista y naturalista decimonónica, la emancipación de la mujer, cuando la hay, está siempre respaldada por un hombre poderoso. La caída o ascenso de una mujer, en la literatura de la época, siempre tiene como protagonista a un varón.

Esta protagonista, junto con sus hermanos, parece partir de un diagrama simbólico, más que de uno histórico: el modelo original francés de provincia, aceptada por el nuevo modelo urbano, pero no corrompida por éste. Probablemente este personaje no refleje una situación real, pero sí se convierte en un tópico aspiracional importante; es ella la fuerza transformadora que mueve toda la novela, la influencia de la mujer provinciana se difunde por la urbe. Por su parte, Denise no se rehúsa a la novedad transformadora de la ciudad. Esto es reflejo de algo muy en boga en la literatura decimonónica: la inclusión del hombre/mujer de campo en el proyecto liberal civilizatorio. Zola, consciente de que la cultura rural es golpeada por el modelo civilizador urbano, decide integrarla en el nuevo espacio, no hay otra opción si se quiere evitar la desintegración de las formas tradicionales. El modelo urbano absorbe los aportes de la provincia y los implanta en su proyecto.

La unión final entre Octave y Denise, la pareja de parvenus, con todo y sus vaivenes e ironías, da un cariz más positivo al ciclo de Los Rougon-Macquart. Denise se transforma socialmente, incluso físicamente, pero llama la atención cómo no cambia ni un poco su fuerza moral; durante toda la novela se le describe como «dulce y sensata» (p. 287). Lo mismo sucede con sus hermanos, quienes son descritos de principio a fin como dulces y virtuosos; Jean, un joven de veintidós años al cierre de la novela, es un muchacho obrero, bello y casado que, a fuerza de trabajo, vive feliz y honradamente.

El muchacho siempre es descrito desde una belleza femenina, así al inicio: «tenía una belleza de muchacha, una belleza que parecía haberle robado a su hermana: el cutis radiante, el cabello rojizo y ensortijado; los ojos y los labios húmedos de ternura» (p. 6), y así al final: «ancho de espaldas, le sacaba a su hermana la cabeza y conservaba su femenina belleza y su rubia cabellera, que despeinaban esas arrebatadas ráfagas de los obreros artistas» (p. 289). Pépé, por su parte, «seguía mostrando una mimosa dulzura» (p. 289). Los hermanos Baudu conservan, a lo largo de la novela, su virtud intacta y sus atributos naturales y «femeninos» propios de los «mensajeros de la felicidad».

En este punto la novela parece dialogar con el pensamiento de la creación de un mundo nuevo, de un hombre nuevo, presente ya en el Romanticismo, acrecentado con el pensamiento liberal, expuesto en el siglo XIX en las teorías de Robert Owen y Charles Fourier y que se concreta en Francia con la filosofía de 
Henri de Saint-Simon; sus discípulos crean en 1833 la publicación L'homme nouveau ou le messager du bonheur (Dayan-Herzbrun 2005: 85); desde esta teoría, con un cambio en el entorno, el hombre natural, particularmente niños y adolescentes, serían los nuevos elementos que crearían el gran cambio social: «Il ne reste plus qu'à faire: changer l'environnement pour que les humains deviennent différents» (Dayan-Herzbrun 2005: 91). Quizás Zola esté retomando estas ideas, pues reelabora el malestar parisino de estirpe baudelariana acerca del cambio de la faz de la ciudad para proponer una salida: ¿es posible, dado que ya está cambiando el entorno, que se modifique también el ser social de manera positiva? ¿Si es posible mover un edificio, es imposible cambiar el destino del hombre?

La familia natural Baudu sería representante de este homme nouveau y de esta nouvelle femme, «mensajeros de la felicidad»; el apellido de los hermanos es significativo, derivado del francés antiguo baud=joyeux, felicidad, y le otorga un obvio carácter simbólico: los tres jóvenes encarnan la alegría, ni más ni menos. La novela de Zola aporta un giro interesante: la bonheur no la otorga el almacén ni el dinero, sino la nueva mujer, la nueva familia, el nuevo orden social.

Es por eso importante que Denise provenga de la clase trabajadora y que Jean sea descrito también, en la cita que referí antes, como un «obrero artista»; la teoría del homme nouveau emparienta el obrerismo con la infancia y con el hombre natural:

La production de ces hommes nouveaux et de ces femmes nouvelles, qu'il s'agisse d'ouvriers ou de «sauvages», passe par la transformation des conditions de socialisation depuis la prime enfance. Le travail sur l'humain est à la fois travail sur les institutions, les esprits et les corps et il doit commencer dès la prime enfance. (Dayan-Herzbrun 2005: 92)

Este pensamiento surge en una coyuntura histórica propicia al cambio:

L'idée de créer un homme nouveau ou une femme nouvelle est aujourd'hui connotée de façon négative. On y associe les expériences totalitaires, les programmes de biotechnologie et les créatures des œuvres de science-fiction. Elle était en revanche porteuse d'espoir dans ses années de naissance, quand tout paraissait encore possible et souhaitable. On cherchait à échapper au principe d'autorité et au despotisme; on souhaitait bénéficier de l'industrialisation sans subir les conséquences douloureuses du capitalisme. Pas question de se plier à la nécessité économique ou à la fatalité des destins. (Dayan-Herzbrun 2005: 96)

Este proyecto transformador está colocado sutilmente en la novela; prácticamente toda la narración está centrada en el crecimiento monstruoso de los almacenes (al establecimiento se le da constantemente el tratamiento de «monstruo» o «máquina»); es hasta las últimas páginas que la novela toma un giro. A ellas quiero referirme en adelante.

En las escenas finales, Denise, agobiada por los requiebros amorosos, pero ilícitos, de Octave amenaza con abandonar los almacenes. Antes de irse, sin embargo, realiza un último recorrido por el edificio, pero no lo hace sola, sino 
escoltada por los dos hermanos; todos los empleados, es claro, alcanzan a ver en ella a esa nouvelle femme: «al ver a Denise, todos le abrían paso» (p. 293); lo saben, ni por un segundo la empleada ha perdido su virtud, por eso se marcha. Este recorrido tiene como trasfondo un escenario rotundamente blanco, hay una enorme venta blanca donde rige la claridad y la abundancia, el nacimiento del nuevo orden social:

Lo que asombraba a las señoras era el prodigioso espectáculo de la gran venta blanca [...] Caía después desde las bóvedas en una nevada de plumón, una cortina de grandes copos: colchas blancas y cubrepiés blancos colgaban de ellas, ondeando en el aire, como banderas en una iglesia [...] Era lo más grande que había hecho nunca Mouret, la mayor muestra de su genialidad de escaparatista. (p. 283)

Por su parte, Octave se regodea en el triunfo de su imperio, sabe que ha «devorado» a la ciudad: — «contemplando cara a cara esa ciudad que había devorado y a esas mujeres a las que había domeñado» (p. 305)—, pero sufre por amor:

Se iba esbozando en su pensamiento una inconcreta relación: el robo de aquella desdichada, aquella locura definitiva de clienta conquistada, rendida a los pies del tentador, le traía la imagen de Denise, cuyo victorioso talón sentía en la garganta. Se detuvo en lo más alto de la escalera principal y estuvo mucho rato mirando la inmensa nave en la que se apelotonaban todas aquellas mujeres que eran sus súbditos. (p. 303)

Mouret no solo es orgulloso, sino también supersticioso:

El director de unos grandes almacenes de novedades tenía que ser soltero si aspiraba a conservar su regio dominio de varón sobre los deseos desfogados de sus clientes y súbditas: la interposición de una mujer modificaba el entorno y su aroma expulsaba a las demás. (p. 287)

Cede al fin, su triunfo económico y social le hace tomar conciencia de su derrota: ama a Denise y le propone matrimonio frente a un escritorio repleto del dinero de las ventas del día, no sin antes acudir a un inusitado discurso sobre los valores matrimoniales:

Esa superstición de que el matrimonio nos hundiría era una necedad. ¿Es que el matrimonio no es acaso la salud indispensable, la fuerza y el orden mismos de la vida? (p. 306)

Entre lágrimas, la pareja se declara su amor, el amante vencido se desmorona y da paso al triunfo de Denise, la mujer «todopoderosa» (p. 307).

Aparentemente Mouret es

El símbolo del triunfo del progreso sobre la tradición [...] Zola había pasado por una fuerte crisis de pesimismo entre 1880 y 1881 y Au Bonheur des Dames constituyó algo así como una revancha, como un exorcismo, un canto a la vida triunfante encarnada en la 'actividad moderna'. Dicho con sus propias palabras, deseaba mostrar 'la dicha de actuar y el gozo de estar vivo'. (Gallego y García en Zola 1999: 2) 
Casi podría ser así, si el autor no abandonase su característica ironía; el final de la novela es, sin duda, precipitado, y acude a una escena que muestra un chocante contraste: el escritorio repleto de dinero ante el que realiza la propuesta matrimonial. No ha triunfado el progreso sobre la tradición; es la tradición la que ha logrado encontrar un sitio en la modernidad. Octave no es el representante del homme nouveau, sino Denise, y si bien queda expuesto el optimismo de «la alegría en el trabajo» no debe olvidarse que toda la novela está cruzada por la ironía. El triunfo de Denise casi parece un castigo para Mouret... parece que Zola esboza una sonrisa. Desde el inicio de la novela ya se anunciaba el desenlace fatal para Octave en labios de Bourdoncle: «Se vengarán... Llegará una que vengará a las demás; es algo fatal» (p. 26).

Es esta joven y pequeña obrera, David contra Goliat, la que ha vencido al monstruo:

¿Por qué su mano menuda tenía de repente tanto poder sobre la labor del monstruo? Y
aquella fuerza, que barría con todo, la arrastraba a ella también, a ella, cuyo advenimiento
tenía que haber sido una revancha. Mouret había ideado aquella maquinaria que lo
aplastaba todo, cuyo brutal funcionamiento la indignaba. Y, pese a todo, ella lo amaba
porque su obra era grande; lo amaba más y más a cada uno de los excesos de su poder,
pese al caudal de lágrimas que la arrollaba al presenciar la sagrada miseria de los vencidos.
(p. 277)

Llama la atención cómo este personaje, aparentemente menor en el marco de la gran narrativa francesa del siglo XIX, se convierte en el centro del ciclo naturalista de Zola y cómo se trastoca el tópico mujer/acinesia. Retomo el tema de la ironía al que me he referido a lo largo de este artículo: el título, centrado en la historia de un gran almacén, puede parecer frívolo en un inicio, pero el autor le otorga un final que subraya la virtud; el contraste irónico frivolidad/virtud es estupendo y cambia el sentido de toda la novela: la bonheur nunca estuvo en el consumo y la apariencia, sino en la sencillez y el trabajo. Hay también una importante estrategia irónica, un vaivén entre los dos mecanismos propios de la ironía: la hipérbole y la lítote; la hipérbole evidentemente se encuentra en la exageración del éxito de los almacenes y del poderío de Mouret, la lítote en el rebajamiento de Denise, pero es ésta quien, desde su empequeñecida posición, triunfa sobre París. Ha nacido la nouvelle femme.

De tal manera, El paraíso de las damas se inscribe en el marco de reivindicación social propia del autor. Al final, el esquema simbólico de hombres y mujeres nuevos, rectos y trabajadores, se impone al cinismo, al consumo y al artificio de la ciudad. Nace el nuevo ser moderno: limpio, correcto, virtuoso, reflexivo e incluyente. La regeneración de la sociedad, afirma Zola, es posible. 


\section{BIBLIOGRAFÍA}

ÁlVAREZ MORA, A. (2008), «La literatura como marco de reflexión urbana a propósito de tres obras del siglo XIX: La taberna y El paraíso de las damas, de Émile Zola, y Grandeza y decadencia de César Biroteau, de Honoré de Balzac», Ciudades, 11, 275-282.

CAlATRAVA, J. (2007), «En los orígenes de la metrópoli moderna: Émile Zola y el París de Haussmann», en La ciudad: paraíso y conflicto, Calatrava Escobar, J. y González Alcantud J. A. (eds.), Madrid, Abada Editores, 229-257.

DAYAN-HERZBRUN, S. (2005), «Un homme nouveau pour un monde nouveau», Tumultes, 2(25), 85-96. Disponible en : <https://www.cairn.info/revue-tumultes-2005-2-page85.htm>.

HUTCHEON, L. (1992), «Ironía, sátira, parodia. Una aproximación pragmática a la ironía», en De la ironía a lo grotesco (en algunos textos literarios hispanoamericanos), México, Universidad Autónoma Metropolitana, 171-193.

RAMA, A. (1998), La ciudad letrada, Montevideo, Arca.

ZolA, E. (1960-1967), Les Rougon-Macquart, Lanoux A. y Miterrand, H. (eds.), Paris, Gallimard, Bibliotèque de la Pléiade.

ZOLA, E. (1999), El paraíso de las damas, Gallego, M. T. y García, A. (trads. y nota), Madrid, Alba.

ZOLA, E. (1972a), «La novela experimental», en El naturalismo, Bonet, L. (ed.), Barcelona, Ediciones Península, 41-94.

ZOLA, E. (1972b), «El dinero en la literatura», en El naturalismo, Bonet, L. (ed.), Barcelona, Ediciones Península, 147-181. 